\title{
Teacher's perception about the importance of the use of ICT in the classroom. ITICOMTAS and ICOMTISM validation
}

DOI: $10.46932 / \mathrm{sfjdv2n2-090}$

Received in: March 1st, 2021

Accepted in: May 30th, 2021

\author{
Varinia Martínez García \\ Graduada Educación Primaria. Especialista en Audición y Lenguaje. \\ Institution: RG Formación \\ Calle Rosalía de Castro, 44, 30107 Murcia \\ María del Carmen Guirao Carpes \\ Graduada Educación Primaria. Especialista en Audición y Lenguaje. \\ Institution: RG Formación \\ Calle Rosalía de Castro, 44, 30107 Murcia \\ Jose María Rabal Alonso \\ Profesor ISEN Centro Universitario \\ Institution: Universidad de Murcia \\ Calle Menéndez y Pelayo, 8, 30204 Cartagena, Murcia \\ E-mail: josemaria.rabal@um.es
}

\begin{abstract}
This article is the first of a series of research articles aimed at proposing tools aimed at determining the repercussion and impact that the use of Information and Communication Technologies (ICT) has on education, these tools being useful in great measure. measured in all educational stages - from childhood to university stages. In this specific research, a detailed recapitulation of how Information and Communication Technologies are related to interest has been carried out (specifically, to determine if the use of ICTs increases the interest of students towards the realization of activities), as well as with the motivation (study if ICTs promote student motivation) of the students, for whose field research two specific questionnaires are proposed for each of the aforementioned associations. For the creation and implementation of the instruments proposed in this study, we have carried out two major stages: firstly, the construction of the items of the scales themselves and, secondly, an analysis of the judges - expertsand the validation of the instrument for collecting information by them.
\end{abstract}

Keywords: SEN students, LOE, LOMLOE, LOMCE, ICT, TIC.

\section{INTRODUCTION}

In the first place, it is necessary to indicate what Information and Communication Technologies (hereinafter ICTs) consist of. In this sense, it is worth mentioning Eva María Rodríguez Cobos (2009) as she states that "we understand ICTs as the set of products derived from new tools (software and hardware), information media and communication channels related to storage, digitized processing and transmission of information ". 
On the other hand, it is necessary to remember that the Organic Law for the Improvement of Educational Quality (hereinafter LOMCE) modified the powers present in the previous Organic Law on Education (hereinafter LOE). This Law shows how one of the key competences to be acquired by students at the end of the educational stage is none other than digital competence. This competence is worked on in an interdisciplinary manner in all areas of the curriculum and is based on the autonomous and functional use of the aforementionedICTs to obtain, select, modify, originate and exchange relevant information.

With the use of ICTs open up a wide range of possibilities that can be used by teachers in their methodologies to favor the teaching-learning process. In this way, the classes are not based on the traditional unidirectional methodology of the master class, now the student develops an autonomous learning and therefore "an active and innovative methodology is put into practice that motivates the students" (Rodríguez Cobos, 2009) .

Now, we are currently witnessing a process of change in education where practices are becoming more and more inclusive. This new paradigm is based on providing "a quality education to the entire student population, regardless of their personal or social conditions" (García, Romero, Aguilar,Lomeli \& Rodríguez, 2013).

From all this it is extracted that students with specific educational support needs (hereinafter SEN STUDENTS), specifically students with special educational needs (hereinafter SEN STUDENTS) will receive a quality, fair, equitable education and on equal terms with the rest of the their peers and therefore will use the ICTs in the teaching-learning process.

As García and López (2012) point out:

\footnotetext{
We think about how ICT can favor the transformation of educational contexts, to make them more inclusive, thus being an instrument that allows the optimization of educational attention to the diversity of students (p. 192).
}

The interest in the use of these tools lies in the usefulness they show to be able to break down barriers present in the educational system, for example, they offer alternatives to oral communication for those students who cannot access it, they allow those students with diversity motor skills can participate in class activities, thus favoring participation and a host of other benefits.

The ICTs allow teaching to be individualized, as they adapt to the students' centers of interest and consequently increase concentration, motivation and interest in the task. These aspects are of great importance in working with SEN STUDENTS. 


\section{IDENTIFICATION OF VARIABLES AND QUESTIONNAIRES}

Our society has changed in recent years, leading to a change in the educational system that is largely due to the constant development of technology. Information and communication technologies are a great source of knowledge. Therefore, teachers and schoolchildren must acquire skills and abilities to function in the digital world. For this reason, the usability of theICTs by teachers and students (Edel and Colorado, 2015). Specifically, Tortosa (2004) states that ICTs can be decisive in improving the quality of life of people with functional diversity, enabling access to the school curriculum, communication and facilitating their social and work integration. For this reason, we consider our research to be of vital importance.

We will now go on to explain in detail the questionnaires raised.

Variable: School context and resources

objective: Analyze if the center has those ICTs that are necessary for the learning of the apprentices, as well as determine the conditions of the teachers for the management and use of them

Justification - To be able to delve into the importance and improvements that the use of the ICTs in the teaching-learning process for SEN STUDENTS, the first question to be addressed is whether the center has the necessary resources, as well as the skills of the teachers in this area, as Alonso, Gonzálvez and Bartolomé (2016) point out "the The use of electronic devices and resources in the classroom is part of the daily activity in which teachers and students move ". Likewise, it is worth citing Garassini (2010) as he states that currently "a teacher is needed who uses the new information and communication technologies functionally".

The methodology based on the use of these tools supposes an autonomous work on the part of the student, however this does not mean that the teacher sees his work diminished, but quite the opposite. The teacher must modify various aspects of the teaching process, such as the evaluation, prepare specific materials adapted to this new way of working and increase the tutorial work to prepare the students in the tasks of selecting, searching and evaluating the information, such and as Alonso points out,Gonzálvez and Bartolomé (2016).

Therefore, it is essential that the center has the tools ICTs are necessary since, again quoting Garassini (2010) "the incorporation of new information and communication technologies into the educational context has been seen as the possibility of expanding the range of resources, teaching strategies and communication modalities that can be offered for the improvement, optimization and scope of educational work. "

Variable: Communication and literacy skills 
objective: Determine if communication and literacy skills have improved after the use of ICTs

Justification - The work of Hearing and Language with the SEN STUDENTS is based on the work of communication and literacy skills. Teaching with these students is based on the ordinary curriculum and therefore it is equally necessary to include the toolsICTs in the process, as pointed out by Alonso, Gonzálvez and Bartolomé (2016) "technological innovation in ICTs has allowed the creation of new communicative and expressive environments that open the possibility of developing new formative, expressive and educational experiences, enabling the realization of of different activities not imaginable until recently ". In addition, they point out that these new tools used "have dramatically transformed reading, writing and all forms of communication."

Garassini (2010) affirms that it is a requirement that teachers know and use with crITICOMTAS 1 vision the software that exists in the market for the stimulation of written language.

Currently and thanks to the boom that emerging technologies are experiencing, among which are included ICTs, it is possible to find a multitude of games and applications that favor the performance of literacy skills, allowing, in turn, to work in an interdisciplinary way various standards related to Listening and Language skills. For example, the same author cited above maintains that "lElectronic stories are an excellent tool to stimulate children's enjoyment of literature. In addition, for the little ones they are an excellent tool for the beginning or consolidation of literacy since many of them allow listening and reading the story simultaneously, listening to only some words or letters of it, aspects that help children to identification of the different elements of written language within the meaningful context of a story "(Garassini, 2010). In addition to electronic stories, it proposes a series of activities through which to favor the learning process of students using ICTs according to the level of the student, such as virtual visits.

Variable: Social skills and results

objective: Study if there is an improvement in social skills when ICTs are used in activities, as well as the changes experienced in the teachers

Justification - It is necessary to evaluate whether the use of ICT resources implies an improvement in the teaching-learning process or, on the contrary, does not offer superior results than those obtained through traditional teaching and even to make visible bad results.

Alonso, Gonzálvez and Bartolomé (2016) state that these resources improve communication between the different agents of the educational process, since they allow a more personalized teaching. Likewise, these authors show some drawbacks that may result from the use of ICTs, such as a worsening in spelling due to the speed with which it is answered in these tools. 
Regarding social skills, it should be noted that the use of ICTs in classroom activities favor both individual and cooperative work, thus favoring the retention of what has been learned, enhancing crITICOMTAS 1 thinking, increasing the diversity of knowledge and experiences acquired and facilitating the organization of group activities (Alonso, Gonzálvez and Bartolomé, 2016). However, various studies have analyzed that the excessive use of ICTs is related to cases of bullying.

García and González (2013), affirm that through various methodologies in which the ICTs, such as telematic educational projects, collaborative learning is favored, characterized by: reflective group discussion, knowledge is a social construct and the educational process is a form of social interaction in an environment rich in information and opportunities for cooperation between equals and meta-cognitive skills should be promoted, such as learning to learn and solve problems working in a group (García and González, 2013). Similarly, these authors argue that through the aforementioned collaborative learning "information and communication technologies have the role of creating new possibilities of social mediation, creating collaborative learning environments that facilitate students to carry out activities together, activities integrated with the real world,

\section{ITICOMTAS QUESTIONNAIRE -INTEREST THAT INFORMATION AND COMMUNICATION TECHNOLOGIES AROUSE IN STUDENTS:}

The following questionnaire has as a study variable the interest that the ICTs can arouse - or arouse - in our students and its primary objective is to determine if the use of ICTs increases the interest of students towards carrying out activities

Interest is justified as a variable since it is intended to check whether the use of ICTs increases this —interest - of students in the educational field, since taking authors such as Inmaculada Fernández (2010) as a reference, one of the advantages of using ICTs is the increased interest on both sides (teacher and student). It should be noted that interest is a fundamental aspect in the teaching-learning process, since without interest on both sides this process is evoked to failure. Teachers usually have great difficulties in awakening the interest of our students, but through ICTs it is intended to achieve indifferently to the subject studied, since videos, audios or interactive exercises reinforce understanding, being in turn an alternative to traditional resources.

In addition, ICTs can serve as a tool to awaken the interest of students and teachers, as well as motivation, another of our indispensable variables for effective and meaningful learning and that will be presented below, since through technology a more efficient and effective educational practice leading to greater satisfaction, facilitating learning (Cobo, 2005). Therefore, it seeks to increase the interest of 
students through ICTs, which also implies that teachers are responsible for looking for formulas that offer information in a more attractive way than the traditional way (Zambrano, 2007).

Having said all of the above, it is important to expose the variables taken into consideration: namely:

Once conceptually introduced, we can observe in Table 1 (ITICOMTAS Questionnaire) the composition of the questionnaire object of evaluation of the interest that the ICTs arouse in our students.

Table 1 ITICOMTAS questionnaire

\begin{tabular}{|l|l|l|l|l|}
\hline Items & 1. Very little & 2. Little & 3. Quite a lot & 4. A lot \\
\hline $\begin{array}{l}\text { 1. The student shows interest in } \\
\text { technological resources such as the } \\
\text { Tablet, PDI, etc. }\end{array}$ & & & & \\
\hline $\begin{array}{l}\text { 2. The student insists on the use of } \\
\text { technical resources when using other } \\
\text { tools }\end{array}$ & & & & \\
\hline $\begin{array}{l}\text { 3. The student stays longer on the task } \\
\text { when ICTs are used }\end{array}$ & & & & \\
\hline $\begin{array}{l}\text { 4. The student handles technical } \\
\text { resources with skill and inquires when he } \\
\text { does not know any application }\end{array}$ & & & \\
\hline $\begin{array}{l}\text { 5. The student requests information when } \\
\text { technological resources are used }\end{array}$ & & & & \\
\hline $\begin{array}{l}\text { 6. Student requests information when } \\
\text { tasks are presented with pencil and paper } \\
\text { materials }\end{array}$ & & & & \\
\hline $\begin{array}{l}\text { 7. The student prefers to play with the } \\
\text { Tablet instead of playing traditional } \\
\text { games }\end{array}$ & & & & \\
\hline $\begin{array}{l}\text { 8. The student prefers the digitized } \\
\text { version of traditional games (goose, } \\
\text { dominoes, ludo, etc.) }\end{array}$ & & & & \\
\hline $\begin{array}{l}\text { 9. I strive, as a teacher, to investigate and } \\
\text { discover new and more appropriate uses } \\
\text { of ICTs in the classroom }\end{array}$ & & & & \\
\hline
\end{tabular}

\section{ICOMTISM QUESTIONNAIRE -INFORMATION AND COMMUNICATION TECHNOLOGIES AND INCREASING STUDENT MOTIVATION-}

The following questionnaire, as mentioned above and as it can be clearly extracted from its name, has as a study variable the motivation that the ICTs arouse before our students. From this it can be extracted that their study objective is to study whether ICTs promote or promote student motivation.

Following the same line, another of our variables is motivation. We intend to show that the student will be more motivated using theICTs since Fernández (2010) establishes motivation as another of the characteristics of ICTs in the educational field. This author argues that the student will be more motivated using ICT tools because, as we said, new technologies allow more attractive, enjoyable and fun learning. 
Motivation, therefore, is essential since the teacher can have a lot of enthusiasm for their subject but without the motivation of the students it is very difficult to achieve the proposed objectives.

Edel (2004) establishes that the student should be the center of the teaching-learning process, but giving greater relevance to learning. Hence the need to ensure the motivation of our students through technological tools, to increase their participation in the educational process and achieve constructivist learning (Díaz and Fernández, 2010).

What's moreWe can justify our variable based on previous research such as that carried out by Domingo, María; Marquès, Pere (2011) as the results of their research show that motivation increases by $100 \%$.

Once the questionnaire was presented in the theoretical field, we went on to present it in Table 2 (ICONTISM Questionnaire).

Table 2 ICONTISM questionnaire

\begin{tabular}{|l|l|l|l|l|}
\hline Items & 1. Very little & 2. Little & 3. Quite a lot & 4 . A lot \\
\hline $\begin{array}{l}\text { 1. The student maintains a positive } \\
\text { attitude when using technology as a } \\
\text { resource }\end{array}$ & & & & \\
\hline $\begin{array}{l}\text { 2. The student shows signs of joy when } \\
\text { ICTs are used in the activities }\end{array}$ & & & & \\
\hline $\begin{array}{l}\text { 3. The student feels encouraged in } \\
\text { carrying out the activities that are carried } \\
\text { out through ICTs }\end{array}$ & & & & \\
\hline $\begin{array}{l}\text { 4. The student satisfies his academic } \\
\text { needs using ICTs }\end{array}$ & & & & \\
\hline $\begin{array}{l}\text { 5. The student shows great emphasis on } \\
\text { performing tasks and games when using } \\
\text { electronic resources. }\end{array}$ & & & & \\
\hline $\begin{array}{l}\text { 6. The apprentice maintains a dynamic } \\
\text { attitude in carrying out tasks when ICTs } \\
\text { are used in them. }\end{array}$ & & & & \\
\hline $\begin{array}{l}\text { 7. I strive, as a teacher, to investigate and } \\
\text { discover new and more appropriate uses } \\
\text { of ICTs in the classroom }\end{array}$ & & & & \\
\hline
\end{tabular}

\section{CREATION, CONFORMATION AND VALIDATION PROCESS}

To provide an individualized education tailored to the abilities and needs of students, it is necessary to use knowledge and inquiry techniques and methods. In this sense, one of the most useful instruments without a doubt - is the questionnaire since it is an appropriate research instrument especially in the field of social sciences, widely applied in qualitative research, as Ricardo Osorio (2001) says. ).

It should be borne in mind that preparing a questionnaire is not an easy task, since we must know and control different variables. It should also be considered that there are different types of questionnaires.

First, the restricted or closed questionnaire, which asks for short, specific and delimited answers. Its advantages include: it requires less effort on the part of the respondents, it limits the sample responses, 
it is easy to fill out, it keeps the subject on topic, it is relatively objective, and it is easy to classify and analyze. Second, the unrestricted or open questionnaire requests a free response, prepared by the subject. It provides more in-depth answers but is difficult to tabulate and interpret. Finally, the mixed questionnaire comprises open and closed questions.

JW Best (1974), gives different suggestions regarding the construction of questionnaires. Among them, the questionnaires should be short, attractive, have clear and complete instructions, clear questions, easy to interpret and classify.

The use of the rubric to evaluate a research project like this one is also justified, since the evaluation rubrics (Dodge 1997; Villalustre and del Moral, 2010) become an effective tool for both the teacher and the student. In the words of Vera (2008), they are measurement instruments in which criteria are established by levels through the provision of scales that allow determining the quality of student performance in specific tasks. In this way, they allow the teacher to specify which competencies are to be achieved and with what criteria they are to be graded.

In addition, the rubric is an excellent educational option in order to verify the process and the level of student performance (Trillas, 2008).

As mentioned, this is not a mere proposal, but what is presented in this research are two tools, with a detailed theoretical support, as well as a subsequent validation by experts. The process of validation of the questionnaires consisted of distributing them to active professionals, both in Early Childhood Education and Primary Education as well as in university education - thanks to the wide range, the results can be extrapolated to secondary or high school students. All of them were asked to write down the time of completion of these - questionnaires - in order to verify that the completion was done in a short space of time. The result was, on the one hand,

Detailing the procedure object of the conformation of these questionnaires, both were conceived through a double aspect. The first aspect to be considered was the detailed bibliographic analysis that was carried out on the variables related to ICTs and as a result, those of the greatest relevance were obtained, of which two are included in the present study. The second fundamental pillar for the conformation of the questionnaires was the collaboration with experts in the field, some of them consecrated researchers and other active teachers and in direct contact with the current reality of the classrooms, as well as the demands that the students, of Directly or indirectly, they carry out. This process had as its main objective the evaluation of the questions raised in the items, thus obtaining the degree of adequacy in the dimensions offered, as well as the systematic understanding of the items that make up both questionnaires. In total, the group of experts was made up of five professionals, all of them active, and all of them closely related - by training or professional - with the research methodology that arises as well as with the use of ICTs. 
In the first place, it is necessary to indicate what Information and Communication Technologies consist of (hereinafter ICTs). In this sense, it is worth mentioning Eva María Rodríguez Cobos (2009) as she states that "we understand ICTs as the set of products derived from new tools (software and hardware), information media and communication channels related to storage, digitized processing and transmission of information ".

On the other hand, it is necessary to remember that the Organic Law for the Improvement of Educational Quality (hereinafter LOMCE) modified the powers present in the previous Organic Law on Education (hereinafter LOE). This Law shows how one of the key competences to be acquired by students at the end of the educational stage is none other than digital competence. This competence is worked on in an interdisciplinary manner in all areas of the curriculum and is based on the autonomous and functional use of the aforementionedICTs to obtain, select, modify, originate and exchange relevant information.

With the use of ICTs open up a wide range of possibilities that can be used by teachers in their methodologies to favor the teaching-learning process. In this way, the classes are not based on the traditional unidirectional methodology of the master class, now the student develops an autonomous learning and therefore "an active and innovative methodology is put into practice that motivates the students" (Rodríguez Cobos, 2009) .

Now, we are currently witnessing a process of change in education where practices are becoming more and more inclusive. This new paradigm is based on providing "quality education for the entire student population, regardless of their personal or social conditions "(García, Romero, Aguilar, Lomeli \& Rodríguez, 2013).

From all this it is extracted that students with specific educational support needs (hereinafter SEN STUDENTS), specifically students with special educational needs (hereinafter SEN STUDENTS) will receive a quality, fair, equitable education and on equal terms with the rest of the their peers and therefore will use the ICTs in the teaching-learning process.

As García and López (2012) point out:

We think about how ICT can favor the transformation of educational contexts, to make them more inclusive, thus being an instrument that allows the optimization of educational attention to the diversity of students.

The interest in the use of these tools lies in the usefulness they show to be able to break down barriers present in the educational system, for example, they offer alternatives to oral communication for those students who cannot access it, they allow those students with diversity motor skills can participate in class activities, thus favoring participation and a host of other benefits. 
The ICTs allow teaching to be individualized, as they adapt to the students' centers of interest and consequently increase concentration, motivation and interest in the task. These aspects are of great importance in working with SEN STUDENTS.

\section{LIMITATIONS}

It is important to carry out a process of retrospection in order to discern those aspects that could imply certain limitations or, in the specific case of this research, which presents two questionnaires that will be the result - in turn - of future research, that the results reflected in they are not highly truthful.

In this sense, the main limitation that we can consider, especially when dealing with questionnaires, is that the results reflected are not highly truthful and reliable. In this sense, a last item is included that tries to delimit the implications that one or another methodology could produce in the students' perception of ICTs, although it is true, since it is a questionnaire that has as its object a rubric with a scale of Likert type, certain responses could not be defined in detail, however, the items object of the questionnaires presented are clear, specific and concise. A possible action in order to increase the reliability of the study would be to complement these questionnaires with a series of short interviews, which allow to delve into the qualitative component of the research.

\section{CONCLUSIONS AND IMPLICATIONS}

As a criterion to conserve an item, a consonance of at least $75 \%$ of the experts was used, so that, in scores - over five - of three or less in two or more of the judges, the review or discard of the item was carried out. object item. This produced a total of one discard, as well as the reworking of another item. In addition, as proposed by several experts, the division of the items in several questionnaires was positively valued to facilitate their application and understanding.

All this results in two appropriate questionnaires, due to their suitability as well as ease of use, for future lines of research that advocate for quality teaching, looking for those aspects that improve it —or can do it-. 


\section{BIBLIOGRAPHY}

Alonso, M., Gonzálvez, J., \& Bartolomé, Á. (2016). Advantages and disadvantages of use of electronic devices in the classroom: students' perception of grades in communication.

Communication Magazine of the SEECI, (41), 136-154.

Garassini, E. (2010). EVALUATION OF ELECTRONIC RESOURCES AS SUPPORT TOOLS FOR TEACHING READING AND WRITING IN PRESCHOOL AND BASIC EDUCATION. Recovered on 24 March AND WRITING IN PRESCHOOL AND BASIC EDUCATION. https://reposital.cuaed.unam.mx:8443/xmlui/handle/20.500.12579/2094

García, A., \& González, L. (2013). PEDAGOGICAL USE OF MATERIALS AND EDUCATIONAL RESOURCES OF ICT: ITS ADVANTAGES IN THE CLASSROOM. Retrieved on March 24, 2020, from http://postitulo.secundaria.infd.edu.ar/archivos/repositorio/1000/1111/USalaman ca_Recursos_TIC.pdf

Rodríguez Cobos, E. (2009). Advantages and disadvantages of ICTs in the classroom. Cuadernos de Educación y Desarrollo, 1 (9). Retrieved from http://www.eumed.net/rev/ced/09/emrc.htm

García, I., Romero, S., Aguilar, C., Lomeli, K., \& Rodríguez, D. (2013). International terminology on $\begin{array}{llllll}\text { inclusive } & \text { education. } & \text { Scielo, } & 13 & \text { (1). } & \text { Retrieved }\end{array}$ https://www.scielo.sa.cr/scielo.php?script=sci_arttext\&pid=S1409-47032013000100007

García, M., \& López, R. (2012). Exploring, from an inclusive perspective, the use of ICT to address diversity. Journal of Curriculum and Teacher Training, 16 (1), 277-293. Retrieved from https://www.redalyc.org/pdf/567/56724377016.pdf

Cázares L, Cuevas JF. Competency-based planning and evaluation. Foundations and practices for the development of teaching competencies, from preschool to graduate school. Threshes; 2008 ..

Cobo, C. (2005). Information organization and its impact on the usability of interactive technologies. Doctoral thesis of the Autonomous University of Barcelona. In network. Recovered in:http://www.tdx.cat/bitstream/handle/10803/4090/ccr1de1.pdf?sequence=1

Colorado-Aguilar, BL, \& Edel-Navarro, R. (2015). The usability of ICT in educational practice. Journal of Distance Education, (30). Recovered fromhttps://revistas.um.es/red/article/view/232611

Díaz, F. and Hernández, G. (2010). Teaching strategies for meaningful learning. A constructivist interpretation. Mexico: Mc Graw Hill.

DODGE, B. (1997). Building Blocks of a Webquest. In: http://projects.edtech.sandi.net/staffdev/buildingblocks/p-index.htm [02-06-2009

Domingo, Maria; Marquis, Pere. Classrooms 2.0 and the use of ICT in teaching practice. Communicate, vol. XIX, no. 37, October, 2011, pp. 169-175. Communicate group. Huelva, Spain

Edel, R. (2004). Education and the development of cognitive skills. Scientific Network. Science, Technology and Thought. In network. Retrieved from: http://www.redcientifica.com/doc/doc200411134401.html 
Fernandez, I. (2010). ICT in education. Eduinnova.

García, I., Romero, S., Aguilar, C., Lomeli, K., \& Rodríguez, D. (2013). International terminology on inclusive $\quad$ education. $\quad$ Scielo, $13 \quad$ (1). $\quad$ Retrieved from https://www.scielo.sa.cr/scielo.php?script=sci_arttext\&pid=S1409-47032013000100007

García, M., \& López, R. (2012). Exploring, from an inclusive perspective, the use of ICT to address diversity.Curriculum magazine and faculty formation, 16 (1), 277-293. Retrieved from https://www.redalyc.org/pdf/567/56724377016.pdf

Osorio, R. (2001). Questionnaire. Magister. Education.

Rodríguez Cobos, E. (2009). Advantages and disadvantages ofICTs in the classroom. Cuadernos de Educación y Desarrollo, 1 (9). Retrieved from http://www.eumed.net/rev/ced/09/emrc.htm

VERA L., (2008) The Rubric and the Checklist, Department of Education and Social Sciences., InterAmerican University of Puerto Rico.

VILLALUSTRE, L ; DEL MORAL, E. (2010), E-portfolios and evaluation rubrics in ruralnet, Pixel-Bit. Media and Education Magazine, 37.93-105.

Zambrano, F. (2007). The usability between technology and pedagogy, fundamental factors in distance education. University Digital Magazine: UNAM. In network. Recovered in:http://www.revista.unam.mx/vol.8/num5/art35/may_art35.pdf 


\section{ANNEXES}

Questionnaire

Variable: Interest

Objective: To determine if the use of ICTs increases students' interest in carrying out activities

\begin{tabular}{|c|c|c|c|c|}
\hline Items & 1. Very little & 2. Little & 3. Quite a lot & 4. A lot \\
\hline $\begin{array}{l}\text { 1. The student shows interest in } \\
\text { technological resources such as the tablet }\end{array}$ & & & & \\
\hline $\begin{array}{l}\text { 2. The student insists on the use of } \\
\text { technical resources when using other } \\
\text { tools }\end{array}$ & & & & \\
\hline $\begin{array}{l}\text { 3. The student stays longer on the task } \\
\text { when ICTs are used }\end{array}$ & & & & \\
\hline $\begin{array}{l}\text { 4. The student handles technical } \\
\text { resources with skill and inquires when he } \\
\text { does not know any application }\end{array}$ & & & & \\
\hline $\begin{array}{l}\text { 5. The student requests information when } \\
\text { technological resources are used }\end{array}$ & & & & \\
\hline $\begin{array}{l}\text { 6. Student requests information when } \\
\text { tasks are presented with pencil and paper } \\
\text { materials }\end{array}$ & & & & \\
\hline $\begin{array}{l}\text { 7. The student prefers to play with the } \\
\text { tablet instead of playing traditional } \\
\text { games }\end{array}$ & & & & \\
\hline $\begin{array}{l}\text { 8. The student prefers the digitized } \\
\text { version of traditional games (goose, } \\
\text { dominoes, ludo, etc.) }\end{array}$ & & & & \\
\hline
\end{tabular}

Variable: Motivation

Objective: To study if ICTs promote student motivation

\begin{tabular}{|l|l|l|l|l|}
\hline Items & & & & \\
\hline $\begin{array}{l}\text { 1. The student maintains a positive } \\
\text { attitude when using technology as a } \\
\text { resource }\end{array}$ & & & & \\
\hline $\begin{array}{l}\text { 2. The student shows signs of joy when } \\
\text { ICTs are used in the activities }\end{array}$ & & & & \\
\hline $\begin{array}{l}\text { 3. The student feels encouraged in } \\
\text { carrying out the activities that are carried } \\
\text { out through ICTs }\end{array}$ & & & & \\
\hline $\begin{array}{l}\text { 4. The student satisfies his academic } \\
\text { needs using ICTs }\end{array}$ & & & & \\
\hline $\begin{array}{l}\text { 5. The student shows great emphasis on } \\
\text { performing tasks and games when using } \\
\text { electronic resources. }\end{array}$ & & & & \\
\hline $\begin{array}{l}\text { 6. The apprentice maintains a dynamic } \\
\text { attitude in carrying out tasks when ICTs } \\
\text { are used in them. }\end{array}$ & & & & \\
\hline
\end{tabular}

Variable: Academic performance

Objective: Analyze if the performance of the students improves when ICTs are used in the tasks

\begin{tabular}{|l|l|l|l|l|}
\hline Items & 1. Very little & 2. Little & 3. Quite a lot & 4. A lot \\
\hline $\begin{array}{l}\text { 1. The student shows greater attention to } \\
\text { tasks when using ICTs }\end{array}$ & & & & \\
\hline $\begin{array}{l}\text { 2. The student solves the tasks more } \\
\text { easily when they are done using } \\
\text { electronic devices. }\end{array}$ & & & & \\
\hline $\begin{array}{l}\text { 3. The student assimilates the contents } \\
\text { quickly when using ICTs }\end{array}$ & & & & \\
\hline
\end{tabular}




\begin{tabular}{|l|l|l|l|l|}
\hline $\begin{array}{l}\text { 4. The student is able to stay focused on } \\
\text { the task for a longer period of time when } \\
\text { ICTs are used in the tasks. }\end{array}$ & & & & \\
\hline $\begin{array}{l}\text { 5. The student shows better results in the } \\
\text { activities in which ICTs are used }\end{array}$ & & & & \\
\hline
\end{tabular}

Variable: School context and resources

Objective: To analyze if the center has those ICTs that are necessary for the learning of the apprentices, as well as to determine the conditions of the teachers for the management and use of them

\begin{tabular}{|l|l|l|l|l|}
\hline Items & 1. Very little & 2. Little & 3. Quite a lot & 4. A lot \\
\hline $\begin{array}{l}\text { 1. The center has sufficient technological } \\
\text { resources to attend to the diversity of the } \\
\text { students }\end{array}$ & & & & \\
\hline $\begin{array}{l}\text { 2. ICTs are used to promote inclusion in } \\
\text { the center }\end{array}$ & & & & \\
\hline $\begin{array}{l}\text { 3. Common activities are designed for all } \\
\text { students where electronic tools are used }\end{array}$ & & & & \\
\hline $\begin{array}{l}\text { 4. The teaching staff has extensive } \\
\text { training in the management and use of } \\
\text { ICTs. }\end{array}$ & & & & \\
\hline $\begin{array}{l}\text { 5. Teachers periodically review the } \\
\text { applications used to adjust them to the } \\
\text { specific needs of students. }\end{array}$ & & & & \\
\hline
\end{tabular}

Variable: Communication and literacy skills

Objective: To determine if communication and literacy skills have improved after the use of ICTs

\begin{tabular}{|l|l|l|l|l|}
\hline Items & 1. Very little & 2. Little & 3. Quite a lot & 4. A lot \\
\hline $\begin{array}{l}\text { 1. The learner improves in the reading of } \\
\text { words / sentences / texts when using ICTs }\end{array}$ & & & & \\
\hline $\begin{array}{l}\text { 2. There is an increase in comprehensive } \\
\text { and expressive vocabulary in the student } \\
\text { after the use of tablet applications }\end{array}$ & & & & \\
\hline $\begin{array}{l}\text { 3. An increase in spontaneous } \\
\text { communication interventions is shown } \\
\text { when ICTs are used }\end{array}$ & & & & \\
\hline $\begin{array}{l}\text { 4. Improves the discursive coherence of } \\
\text { the student with the use of ICTs }\end{array}$ & & & & \\
\hline $\begin{array}{l}\text { 5. Increases the narrative ability of the } \\
\text { learner after the use of applications of } \\
\text { interest }\end{array}$ & & & & \\
\hline $\begin{array}{l}\text { 6. Improves the student's comprehension } \\
\text { capacity when tasks are carried out } \\
\text { through ICTs }\end{array}$ & & & & \\
\hline
\end{tabular}

Variable: Social skills and results

Objective: To study if there is an improvement in social skills when ICTs are used in activities, as well as the changes experienced in the teachers

\begin{tabular}{|l|l|l|l|l|}
\hline Items & 1. Very little & 2. Little & 3. Quite a lot & 4. A lot \\
\hline $\begin{array}{l}\text { 1. Positive emotions are perceived } \\
\text { (smiles, better predisposition to learning, } \\
\text { etc.) when ICTs are used in the process }\end{array}$ & & & & \\
\hline $\begin{array}{l}\text { 2. The student has a greater capacity to } \\
\text { solve those problems that arise when } \\
\text { ICTs are used. }\end{array}$ & & & & \\
\hline $\begin{array}{l}\text { 3. An improvement in the relationship } \\
\text { between equals is manifested when the } \\
\text { activities are carried out through ICTs }\end{array}$ & & & & \\
\hline
\end{tabular}




\begin{tabular}{|l|l|l|l|l|}
\hline 4. The student is able to carry out & & & & \\
cooperative work when ICTs are used. & & & & \\
\hline $\begin{array}{l}\text { 5. The student is able to interact with their } \\
\text { peers without the need to use an } \\
\text { electronic resource }\end{array}$ & & & & \\
\hline $\begin{array}{l}\text { 6. The student uses ICTs for a long period } \\
\text { in their free time }\end{array}$ & & & & \\
\hline $\begin{array}{l}\text { 7. Improves the teacher-student } \\
\text { relationship when using ICTs }\end{array}$ & & & & \\
\hline
\end{tabular}

